\title{
Aplikasi Literasi Digital Berbasis Web Dengan Metode R\&D dan MDLC
}

\author{
Web-Based Digital Literacy using R\&D and MDLC Methods
}

\author{
Ridha Sefina Samosir ${ }^{1}$, Nuraini Purwandari ${ }^{2}$ \\ ${ }^{1,2}$ Industri Kreatif/Sistem Informasi, Kalbis Institute \\ E-mail: ${ }^{1}$ ridha.samosir@kalbis.ac.id, ${ }^{2}$ nuraini.purwandari@kalbis.ac.id
}

\begin{abstract}
Abstrak
Pada era Revolusi Industri 4.0, teknologi terus berkembang semakin canggih seperti teknologi internet, komputasi awan, dan algoritma machine learning. Teknologi tersebut menjadi salah satu komponen penting perkembangan keilmuan di perguruan tinggi. Dengan internet, banyak sekali literasi berbasis dijital yang dapat dimanfaatkan oleh mahasiswa untuk menambah wawasan atau pengetahuannya. Tetapi sumber literasi yang beredar kurang sistematis atau urutan materi yang kurang tepat. Selain itu, materi tersebut kurang terstruktur atau kurang sesuai dengan capaian pembelajaran mata kuliah yang telah ditentukan. Ada banyak sekali materi literasi yang beredar tetapi belum dapat dipastikan kebenaran dan kevalidan dari materi literasi tersebut karena kebanyakan materi literasi tidak menyertakan sumber referensi. Kondisi seperti ini membuat mahasiswa bingung ketika mengakses materi tersebut. Mahasiswa tidak dapat memastikan tingkat kebenaran dan ketepatan dari materi tersebut. Oleh karena itu, penelitian ini mengusulkan sebuah media literasi dijital berbasis teknologi yang dapat dikustomisasi sesuai kebutuhan perguruan tinggi baik dari sisi isi, struktur maupun atribut lainnya. Hal ini berarti bahwa materi literasi yang disajikan dapat disesuaikan dengan capaian pembelajaran yang telah dirumuskan oleh institusi. Sehingga tujuan dari penelitian ini adalah pembuatan sebuah media literasi dijital yang menyajikan materi pembelajaran secara sistematis dan terstruktur bagi mahasiswa di perguruan tinggi. Sistem literasi dijital ini dibangun dengan menggabungkan metode R\&D dan MDLC.
\end{abstract}

Kata kunci: literasi, dijital, r\&d, mdlc, website

\begin{abstract}
During the Industrial Revolution 4.0 era, technology continued to develop more sophisticated such as internet, cloud computing, and machine learning. This technology has become important things of scientific development in higher education. With the internet, a lot of digital-based literacy can be used by students to add insight or knowledge. But the most existing literacy sources are less systematic or incorrect material order.Other than that, the material is less compatible with the learning outcome which determined by the higher education. There are a lot of literacy materials that can not be guaranteed the truth and the validity. This condition occurs confusing for the student while accessing that literacy. Therefore, this study proposes a digital literacy media based on technology for that can be customized according to higher educations needs both in term of content, structure, and other attributes. The literacy material is proposed in this study in line with learning outcome which determined by university. The literacy system was built with a combination of $R \& D$ and MDLC methods. This customizable digital literacy media can be widely used by various universities.
\end{abstract}

Keywords: literation, digital, $r \& d$, mdlc, website 


\section{PENDAHULUAN}

Literasi secara umum diartikan sebagai kemampuan seseorang untuk mengolah dan memahami informasi ketika proses membaca atau menulis. Dari infomasi tersebut maka literasi dijital diartikan sebagai kemampuan untuk memanfaatkan perangkat dijital dalam rangka mencari, menggali, memahami, dan mengolah berbagai informasi yang diperoleh melalui aktifitas membaca dan menulis.

Perkembangan teknologi semakin meningkat sejalan dengan revolusi industri 4.0. Terjadi perkembangan kemampuan (kinerja) komputer terutama dengan tambahan jaringan internet pada berbagai platform seperti mobile dan website. Berdasarkan data yang dikeluarkan oleh Internet World Stats, pengguna internet di Indonesia pada 31 Desember 2000 sebanyak 2 juta. Dengan perkembangan internet sebanyak $7.063 \%$ selama 7 tahun, Indonesia berada pada urutan kelima sebagai negara dengan pengguna internet yang mencapai 143,26 juta jiwa pada 31 Desember 2017 seperti pada Tabel Pengguna Internet di Indonesia [1].

Mahasiswa sebuah perguruan tinggi merupakan representasi dari calon sumber daya manusia (SDM). Salah satu cara menigkatka kemampuan dari mahasiswa adalah dengan banyak membaca atau menggali informasi terkait keilmuan mereka. Saat ini, mahasiswa lebih banyak bertumpu pada perangkat mobile yang terkoneksi dengan jaringan internet untuk mencari berbagai informasi saat mereka berliterasi. Dunia mereka berubah menjadi serba dijital, sehingga menyebabkan popularitas sumber literasi dalam bentuk hard cover seperti buku, jurnal, majalah, dan lain-lain mengalami penurunan. Budaya membaca buku sudah mulai ditinggalkan dengan kehadiran teknologi dijital yang jauh memberikan kemudahan.

Beberapa penelitian telah banyak dilakukan terkait literasi dijital seperti penelitian oleh I Kadek Bangkit Ardana, Luh Gede Surya Kartika, dan Ida Bagus Suradarma. Ketiga peneliti ini mengangkat judul penelitian berupa Rancang Bangun Aplikasi Media Pembelajaran Perkawinan Agama Hindu Dalam Manawa Dharmasastra Berbasis Windows Phone. Multimedia pembelajaran ditujukan untuk menyajikan tata cara pernikahan bagi agama hindu. Media yang digunakan untuk menyajikan informasi tata cara pernikahan berbasis mobile. Sehingga materi pembelajaran dapat diakses melalui perangkat mobile. Menurut penelitian, latar belakang dibangun sistem pembelajaran kurang dipahami oleh masyarakat modern. Informasi yang disajikan oleh aplikasi meliputi Manawa Dharma Sastra, Jenis Perkawinan, Tata Cara Perkawinan, Syarat-syarat Perkawinan, Tujuan Perkawinan, dan Arti Kidung. Selain materi perkawinan Hindu, terdapat juga informasi mengenai Petunjuk Penggunaan aplikasi dan Tentang yang berisi informasi mengenai pembuat aplikasi ini. Aplikasi dikembangkan dengan perangkat lunak Visual Studio 2010 dan bahasa pemrograman bahasa C\# [2]. Penelitian berikutnya adalah yang dilakukan oleh Zaiful Bahri dan Sukamto dari Universitas Riau. Penelitian ini berjudul Aplikasi Evaluasi Pembelajaran Berbasis Multimedia Interaktif Menggunakan PHP dan MySQL. Adapun tujuan penelitian ini adalah membangun aplikasi untuk melakukan test atau uji kompetensi berupa UTS dan UAS kepada mahasiswa sehingga uji tidak lagi melibatan kertas atau media cetak. Metode perancangan yang digunakan adalah Unified Modelling Language (UML). Perangkat yang digunakan adalah perangkat lunak Flash, PHP dan MySQL [3]. Penelitian lainnya adalah penelitian yang dilakukan oleh Hadi Sutopo tahun 2019. Penelitian beliau menggunakan metode MDLC untuk membangun sistem pembelajaran berupa tutorial tentang NARKOBA (narkotika dan obat terlarang) [4]. Heru T.T.W dan Yulia.E juga melakukan penelitian terkait literasi dijital bagi generasi milenial. Kedua peneliti ini mangangkat permsalahan literasi informasi bagi para kaum milenial sesuai dengan karakter dari para milenial yang kreatif, aktif, inovatif, dan modern. Menurut kedua peneliti, meningkatnya kemampuan berbagai media literasi berbasis dijital ini akan sejalan dengan penyebaran berbagai informasi baik informasi benar atau informasi sesat (palsu). Hal ini yang menjadi fokus penelitian bahwa para milenial harus memiliki kemampuan atau komptensi untuk dapat memilih dan memilah informasi yang beredar dengan benar [5]. Sehingga dapat meminimalkan penyalahgunaan informasi yang kurang jelas atau berita palsu (HOAX). Sejalan 
juga dengan penelitian yang dilakukan oleh M.Firman dan Filia.D.A. Kedua peneliti ini menfokuskan kegiatan litrasi dijital bagi mahasiswa yang sedang menulis skripsi melalui kegiatan penelitian. Kedua peneliti ini merekomendasikan sebuah istilah self directed learning ketika menyusun skripsi, dan salah satu teknik melakukan self directed learning adalah dengan berliterasi. Mahasiswa yang menyusun skripsi ini juga dapat memanfaatkan berbagai media dijital untuk berliterasi dalam rangka mencari dan menggali semua materi yang ia butuhkan [6]. Penelitian terkahir adalah penelitian yang dilakukan oleh Juliana.K.S.B. Peneliti ini mencoba membuat peta literasi dijital di sebuah universitas. Peta ini menggambarkan bagaimana kecendrungan mahasiswa disana dalam memafaatkan media dijital untuk berliterasi. Adapun hasil penelitian menujukkan bahwa universitas tersebut berada pada kategori sedang terkait pemahaman mengenai media dijital dan pada kategori dasar untuk melakukan literasi dengan media dijital .

Dari penelitian yang telah dilakukan sebelumnya menunjukkan bahwa walaupun teknologi internet sangat membantu mahasiswa untuk mengakses berbagai sumber literasi yang berbasis dijital, namun materi yang tersaji sering sekali tidak sistematis dan tidak terstruktur. Materi literasi yang disajikan sering sekali tidak memiliki urutan penyajian yang baik, materi yang disajikan terlalu sempit atau terlalu luas sehingga fokus materi cenderung tidak tercapai, dan materi tersebut juga sering sekali bukan berdasarkan hasil penelitian atau dari sumber referensi yang baik atau valid. Pada lain pihak, para pelaku bisnis juga selalu memanfaatkan media dijital sebagai promosi produk mereka. Demikian juga dengan keberadaan berbagai pihak yang kurang bertanggungjawab yang sering menyajikan informasi sesat atau informasi palsu. Kondisi ini menjadi permasalahan karena mereka tidak dapat mengetahui kebenaran atau ketepatan sumber referensi yang ia peroleh. Bahkan pada kondisi tertentu, mengingat banyaknya informasi dijital tersebut maka mahasiswa menjadi bingung bagian mana yang dapat ia gunakan [7]. Hal ini menjadi suatu tantangan sekaligus peluang dalam upaya untuk menciptakan media sebagai sumber literasi berbasis dijital. Materi literasi dijital diharapakan lebih tersruktur dan sistematis. Sistematis berarti ada urutan-urutan materi yang jelas sesuai dengan kebutuhan keilmuan nya. Sedangkan terstruktur berarti materi dari sumber literasi dijital yang diusulkan tersebut disesuaikan dengan capaian pembelajaran (learning outcome) yang ingin dicapai atau ada fokus sasaran yanag ingin dicapai setelah mahasiswa mempelajari materi tersebut.

Dari studi literatur juga menunjukkan bahwa media-media pembelajaran berbasis teknologi tersebut dikembangkan hanya dengan melibatkan metode pengembangan sistem berbasis teknologi yaitu metode MDLC. Sesuai dengan prinsip dari metode MDLC maka penelitian hanya fokus pada keberhasilan terciptanya sebuah produk berbasis teknologi tersebut. Selain itu, evaluasi hanya dilakukan berdasarkan kesesuaian kebutuhan fungsional dari produk teknologi yang dihasilkan. Padahal sebagai produk yang akan digunakan oleh banyak pihak maka perlu dilakukan pengujian efektifitas terhadap produk tersebut. Pengujian efektifitas ini bertujuan untuk mengidentifikasi dampak atau manfaat kepada penggunanya setelah menggunakan produk tersebut. Selain itu, dapat diketahui dampak yang diperoleh setelah menggunakan produk literasi dijital ini. Apabila hasil pengujian efektifitas produk maka dapat dipastikan bahwa kualitas dari materi literasi dijital telah memenuhi kebutuhan awal yaitu materi literasi dijital yang sistematis dan terstruktur. Dengan latar belakang ini maka tim peneliti mengusulkan pemanfaatan gabungan dua metode yaitu metode R\&D dan MDLC dalam rangka mengembangkan media literasi dijital dengan penyajian materi literasi yang terstruktur dan sistematis.

\section{METODE PENELITIAN}

Objek penelitian yang diusulkan adalah materi pada sumber literasi dijital dengan salah satu pengguna adalah mahasiswa. Pada penelitian ini, materi literasi menyesuaikan dengan kurikulum di Pergruan Tinggi. Jadi objek penelitian ini adalah materi literasi dijital untuk Perguruan Tinggi. Sumber literasi dijital yang diusulkan ini akan melibatkan tiga pengguna 
yaitu mahasiswa, ketua program studi, dan dosen penyusun materi literasi dijital. Mahasiswa sebagai pengguna yang mengakses materi literasi dijital tersebut. Dosen adalah pengguna yang berperan sebagai penyusun materi literasi dijital. Sedangkan ketua program studi adalah pengguna yang berperan untuk memetakan dosen penyusun materi literasi sesuai dengan kompetensi keilmuan dosen dan melakukan verifikasi terhadap materi literasi yang telah dikirim oleh dosen. Materi literasi dijital tidak digunakan secara langsung dalam kegiatan perkuliahan di kelas, tetapi digunakan sebagai tambahan sumber literasi mahasiswa.

\subsection{Metode Penelitian}

Penelitian ini mengusulkan gabungan dua metode penelitian yaitu R\&D dan metode MDLC [8]. Pemilihan metode R\&D adalah karena sesuai dengan tujuan penelitian yaitu membuat sumber literasi dijital dan sumber literasi dijital ini adalah salah satu produk jenis pendidikan yang berfungsi sebagai media pembelajaran. Keluaran dari penelitian ini diharapkan dapat digunakan oleh banyak pihak sehingga perlu dilakukan validasi dalam rangka menguji efektifitas dari keluaran penelitan. Hal ini yang menjadi alasan mengapa metode R\&D digunakan. Sedangkan agar produk yang dihasilkan benar-benar memenuhi kebutuhan fungsional dari calon pengguna maka metode MDLC dilibatkan. Penggabungan kedua metode ini diharapkan dapat dihasilkan sebuah produk berbasis teknologi yang memenuhi kebutuhan fungsional dan sekaligus memberikan dampak kepada pengguna karena teruji efektifitasnya.

Metode R\&D digunakan untuk menghasilkan sebuah produk dan menguji keefektifan dari produk tersebut. Untuk menghasilkan produk diperlukan analisis kebutuhan dengan metode survey atau kualitatif. Dan untuk menguji efektifitas produk apakah dapat digunakan oleh pengguna luas maka dilakukan metode eksperimen atau action research. Apabila produk telah teruji maka produk dapat diaplikasikan. Jadi metode R\&D bertujuan untuk menemukan, mengembangkan, dan memvalidasi sebuah produk. Terkait prinsip dari metode R\&D yaitu menemukan, mengembangkan, dan validasi sebuah produk maka seluruh tahapan dalam metode $\mathrm{R} \& \mathrm{D}$ tepat digunakan dalam penelitian ini. Walaupun pada penelitian tahap pertama ini, belum dapat dilakukan pengujian keefektifan dari produk yang dihasilkan. Hal ini karena, penelitian saat ini baru sampai di tahap perbaikan produk awal. Penelitian akan dilanjutkan pada tahap kedua setelah proses perbaikan produk awal selesai dilakukan. Dan publikasi hasil tahap kedua akan disusun pada artikel ilmiah lainnya.

Metode R\&D merupakan singkatan dari research and development. Research berarti penelitian ini akan menggali mengapa literasi dijital dibutuhkan sebagai media pembelajaran, menggali permasalahan-permasalahan dari sumber literasi dijital yang ada saat ini, menggali isi materi literasi dijital yang dibutuhkan, menggali capaian pembelajaran yang ingin dicapai dari materi literasi, dan lainnya.

Sedangkan development berarti dari hasil research maka dapat dikembangkan produk yang memenuhi semua kebutuhan baik fungsional maupun non fungsional. Dari seluruh data yang terkumpul dari hasil research maka kebutuhan fungsional yang teridentifikasi adalah adalah perlunya sebuah media berbasis dijital yang dapat menyajikan materi literasi yang terstruktur dan sistematis. Proses development juga memastikan proses pengujian terhadap produk tersebut sehingga produk tersebut layak digunakan. Selain itu, juga dilakukan evaluasi terhadap hasil penerapan dari produk tersebut sehingga diketahui dampak terhadap pengguna setelah menggunakan produk tersebut [9].

Metode MDLC (Multimedia Development Life Cycle) digunakan sebagai metode untuk mengembangkan sistem (produk) yang diusulkan [10]. Pada proses perancangan sistem, penelitian ini menggunakan metode pemodelan UML (Unified Modelling Language) [11]. Sedangkan metode yang digunakan saat ujicoba awal terhadap produk yang adalah metode black box. Metode black box bertujuan untuk menguji fungsional dari sistem berdasarkan requirement awal [12]. 


\subsection{Tahapan Penelitian}

Tahapan dalam penelitian ini merupakan gabungan tahap dari metode R\&D dan MDLC. Metode MDLC terdiri dari 6 (enam) tahap yaitu concept, design, obtaining content material, assembly, testing, dan distribution. Sedangkan metode R\&D terdiri dari 10 tahap, yaitu:

1. Penelitian dan Pengumpulan Data Awal (Research and Preliminary Information Collecting).

2. Perencanaan (Planning).

3. Pembuatan Produk Awal (Developing Preliminary Product).

4. Uji Coba Awal (Preliminary Testing).

5. Perbaikan Produk Awal (Preliminary Product Revision).

7. Uji Coba Lapangan (Main Field Testing).

8. Perbaikan Produk Operasional (Operational Product Revision).

9. Uji Coba Operasional (Operational Testing).

10. Perbaikan Produk Akhir (Final Product Revision).

11. Deseminasi (Dissemination and Implementation)

Penggabungan kedua metode penelitian yang diusulkan adalah pada tahap ketiga dari metode R\&D. Pada tahap ketiga ini, metode kemudian digabungkan dengan tahapan pada metode MDLC.

Penelitian ini dibagi menjadi dua tahap yaitu tahap 1 dan tahap 2. Tahap 1, penelitian akan dilakukan sampai dengan 5 (lima) tahap dari metode R\&D yaitu sampai dengan tahap perbaikan produk awal. Berdasarkan penjelasan tersebut maka artikel ilmiah ini adalah publikasi tahap 1 yaitu hanya sampai pada tahap perbaikan produk awal. Gambar 1 merupakan ilustrasi dari kombinasi kedua metode yang digunakan.

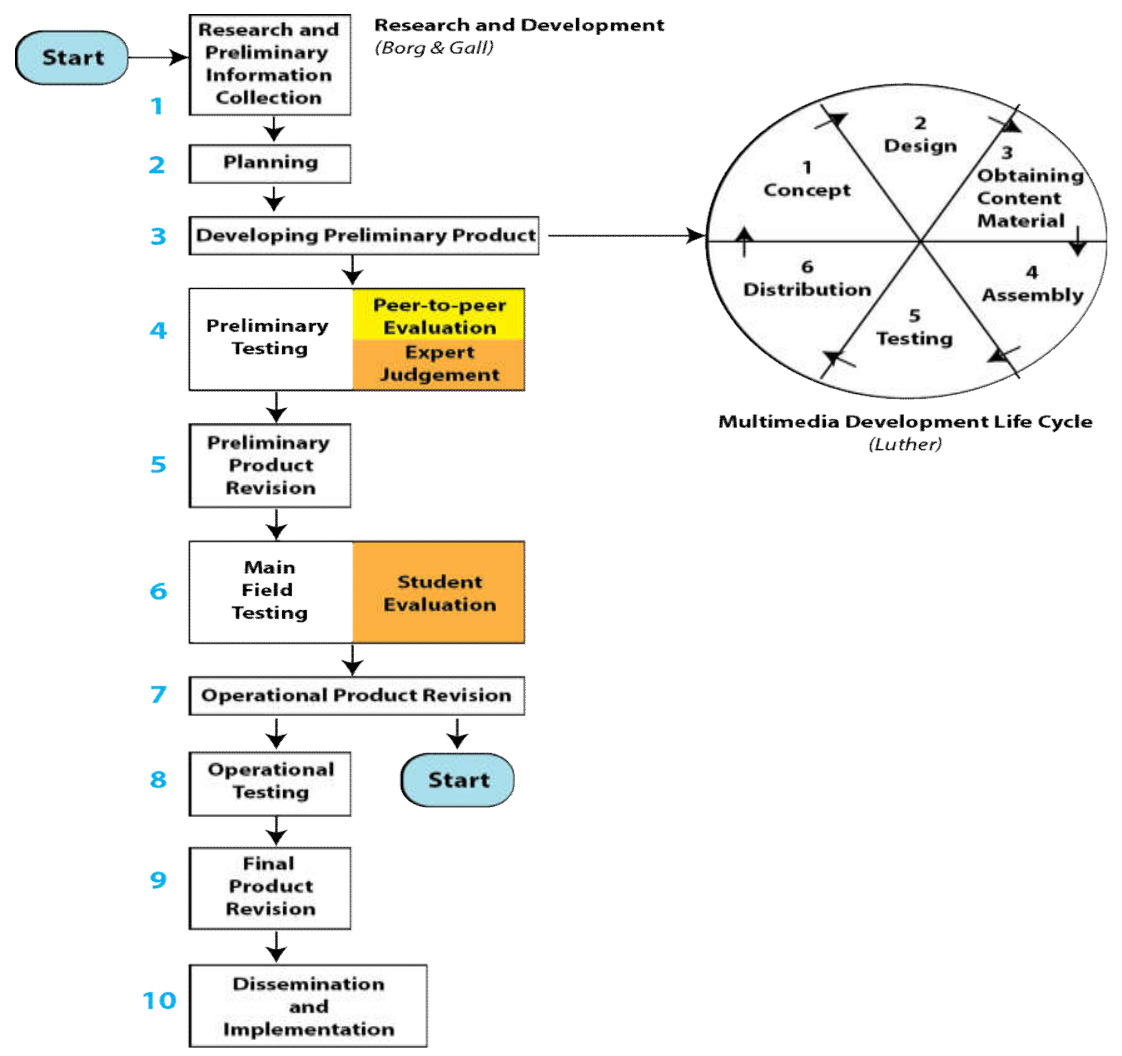

Gambar 1 Ilustrasi Kombinasi Metode R\& D Dengan MDLC 


\section{HASIL DAN PEMBAHASAN}

Adapun hasil dari penelitian ini adalah seluruh hasil dari setiap tahap penelitian yang dilakukan, tepatnya tahap 1 sampai tahap 5 dari metode R\&D yang dikombinasikan dengan tahap 1 sampai 6 dari metode MDLC.

\subsection{Riset dan Pengumpulan Informasi}

Pada tahap penelitian dan pengumpulan data ini dilakukan melalui studi literatur dan observasi. Hasil observasi diperoleh data contoh capaian pembelajaran dari beberapa mata kuliah, materi literasi yang ingin disajikan berdasarkan capaian pembelajaran, kompetensi atau keahlian dosen, sumber referensi yang digunakan oleh setiap mata kuliah, dan data lainnya. Observasi juga dilakukan pada beberapa sumber literasi dijital yang tersedia banyak saat ini melalui platform website maupun mobile. Sehingga dapat diketahui potensi-potensi permasalahan dari sumber literasi dijital yang ada saat ini. Sedangkan dari hasil studi literatur diperoleh beberapa hasil penelitian sebelumnya yang relevan dengan topik yang diusulkan. Melalui studi literatur dapat diketahui metode-metode yang pernah digunakan sebelumnya dan bagaimana hasil evaluasi dari penerapan metode tersebut. Perpaduan dari kedua langkah yaitu studi literatur dan observasi diperoleh permasalahan yang ingin diselesaikan serta kebutuhannya. Peneliti juga mendapatkan informasi perkembangan literasi-literasi dijital yang telah dan pernah dikembangkan oleh peneliti lain pada periode sebelumnya.

Dari tahap riset dan pengumpulan data ini maka permasalahan dari penelitian ini adalah bagaimana cara menyajikan materi literasi yang dapat diakses kapan saja dan dimana saja oleh banyak pengguna tetapi tidak menyimpang dari capaian pembelajaran yang telah ditentukan atau dengan kata lain materi tersebut disajikan dengan teratur dan sistematis. Tabel 1 merupakan contoh hasil pengumpulan data kompetensi dosen.

Tabel 1 Keilmuan Dosen

\begin{tabular}{|c|c|c|}
\hline Nomor & Inisial Dosen & Keilmuan \\
\hline 1 & RSS & Data Warehouse, Data Mining, APSI \\
\hline 2 & MZ & SPK, Algoritma, APSI \\
\hline 3 & NP & Pengembangan SI, Sistem Multimedia \\
\hline 4 & AK & Pengembangan SI, Tata Kelolah, Audit SI/TI \\
\hline 5 & JG & SIG, Data Mining, Pemrograman \\
\hline 6 & HF & Pengembangan SI, KMS, Audit SI/TI \\
\hline
\end{tabular}

\subsection{Perencanaan}

Tahap berikutnya adalah perencanaan. Keluaran dari tahap ini adalah berupa usulan rencana penelitian yang meliputi rumusan keahlian yang berkaitan dengan permasalahan, penentuan tujuan yang ingin dicapai pada setiap tahapan, dan desain atau lagkah-langkah penelitian. Sesuai dengan permasalahan di atas maka penelitian ini mengusulkan solusi berupa sistem literasi dijital bagi perguruan tinggi dengan platform website yang dapat dikustomisasi sesuai dengan kebutuhan. Adapun kecakapan atau keilmuan dari rencana penelitian ini melibatkan keilmuan bidang komputer yaitu sistem informasi. Adapun desain atau langkahlangkah penelitian dilakukan untuk menggali rencana materi literasi yang akan disajikan, rencana metode pembuatan produk, rencana metode pengujian produk, dan rencana lainnya berdasarkan usulan solusi tersebut. Berikutnya adalah tahap ketiga metode R\&D yaitu pembuatan produk awal.

\subsection{Pembuatan Produk Awal}

Sesuai penjelasan sebelumnya bahwa saat pembuatan produk awal, peneliti menggunakan metode MDLC dengan tahapan dari konsep sampai dengan distribusi. Pada tahap konsep, diverifikasi tujuan dari produk serta pengguna produk. Adapun tujuan dari teknologi atau sistem yang diusulkan adalah sebagai media literasi dijital bagi mahasiswa di perguruan 
tinggi. Sumber literasi dijital diartikan sebagai sebuah media yang berisi materi pembelajaran yang diharapkan dapat dengan mudah difahami oleh mahasiswa karena melibatkan komponen multimedia dalam penyajian materi nya. Adapun target pengguna dari sistem usulan adalah mahasiswa-mahasiswa, dosen, dan ketua program studi.

Pada tahap desain dijelaskan hasil pemodelan dari sistem usulan meliputi pemodelan sistem dengan unified modelling language (UML), desain basisdata, desain struktur navigasi, dan desain antar muka grafis [13]. Pemodelan dengan UML direpresentasikan dalam usecase diagram, activity diagram, dan class diagram. Gambar 2, dan 3 berturut-turut adalah usecase diagram dan class diagram dari sistem usulan.

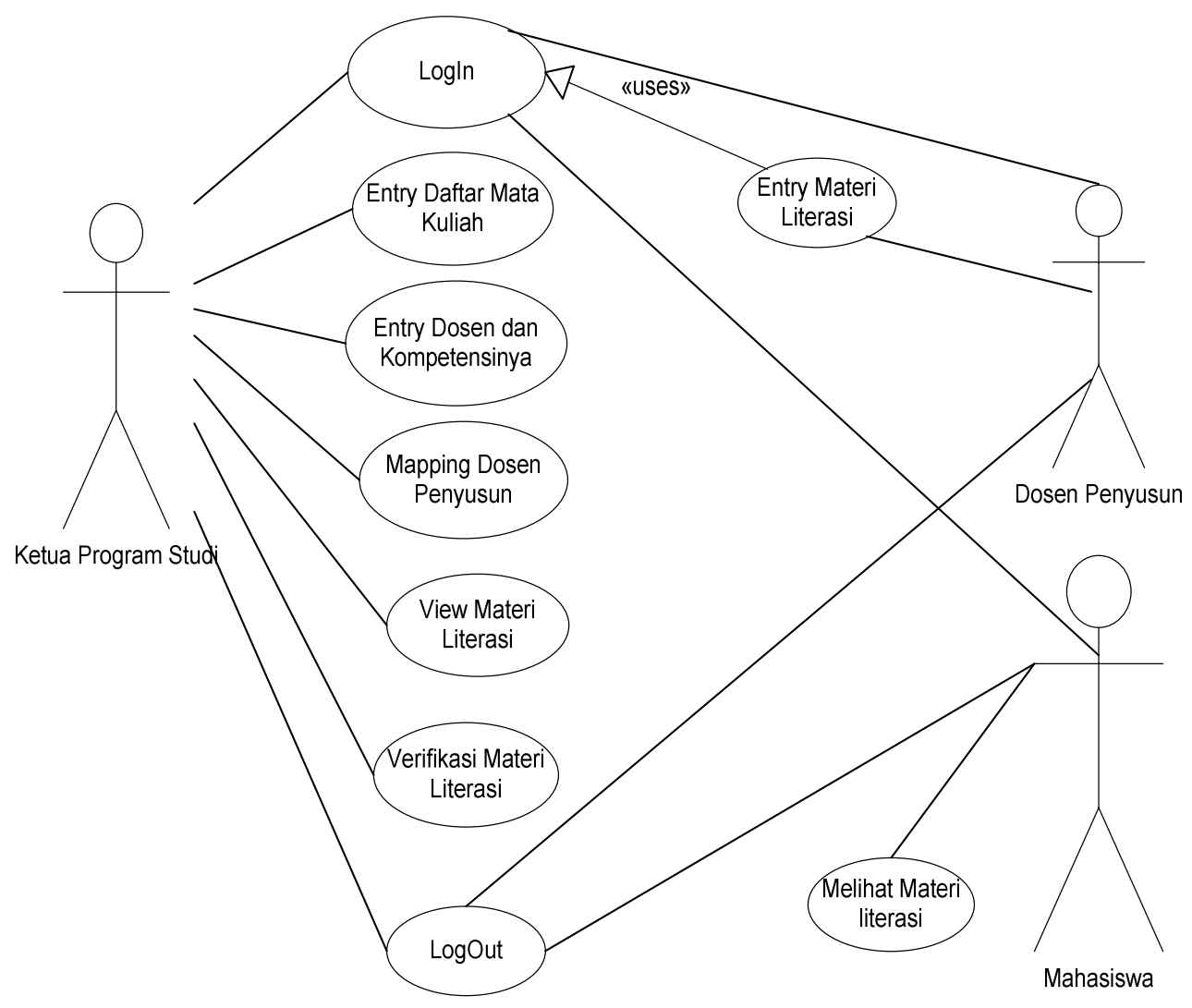

Gambar 2 Use Case Diagram Sistem Literasi Dijital

Dari usecase diagram di atas menunjukkan bahwa ada tiga pengguna (user) yaitu mahasiswa, dosen, dan ketua program studi. Ketiga pengguna tersebut memiliki hak akses yang berbeda. Mahasiswa hanya dapat melihat materi literasi dijital. Dosen yang menyusun materi literasi dijital dengan proses verifikasi oleh ketua program studi. Sehingga usecase dari dosen adalah submit dan view materi literasi. Submit berfungsi untuk meneruskan materi yang telah ia susun kepada ketua program studi. Sedangkan view berfungsi untuk melihat kembali secara keseluruhan materi yang ia susun sebelum dikirim kepada ketua porgam studi. Sedangkan pengguna sebagai ketua program studi memiliki hak akses untuk memetakan dosen yang akan membuat materi literasi dan memverifikasi materi literasi yang telah dikirim oleh dosen penyusun. Verifikasi akan mengubah status dari materi literasi dijital tersebut yaitu ketika ketua program studi telah memverifikasi maka materi literasi dijital akan muncul di akun mahasiswa. Dan di akun dosen, materi literasi yang dapat dilhat adalah materi literasi yang telah diverifikasi ketua program studi. Seluruh proses yang dilakukan oleh ketiga pengguna tersebut disimbolkan dalam bentuk use case diagram. 
Selanjutnya adalah memodelkan kelas-kelas dari objek yang terlibat pada sistem usulan. Pemodelan objek ini divisualkan dengan sebuah class diagram. Dari gambar 3 terlihat bahwa ada 3 kelas yang terbentuk yaitu mahasiswa, dosen, dan ketua program studi. Setiap kelas tersebut mengandung atribut dan metode yang berbeda-beda sesuai dengan fungsi masingmasing kelas. Demikian juga jenis hak akses terhadap atribut maupun metode dari setiap kelas. Ada atribut yang dapat diakses oleh seluruh kelas tetapi ada juga yang hanya dapat diakses oleh kelas itu sendiri. Demikian juga dengan metode, metode view dari kelas mahasiswa dapat diakses oleh seluruh kelas tetapi metode mapping dari kelas ketua program studi tidak dapat diakses oleh kelas apapun.

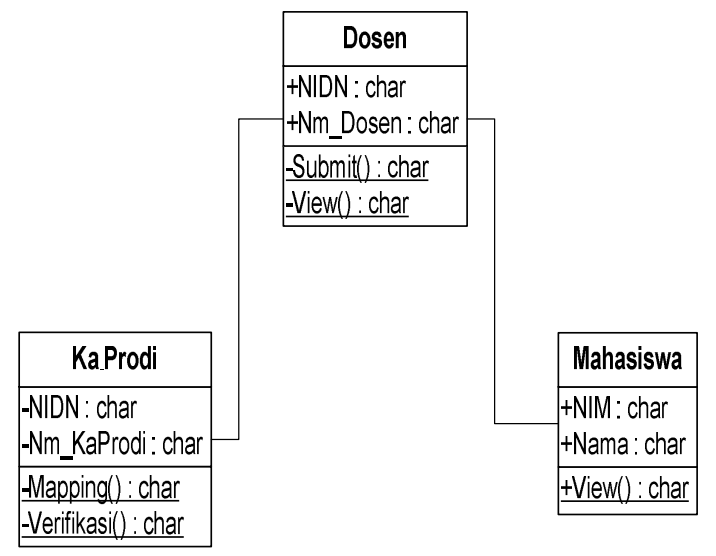

Gambar 3 Class Diagram Sistem Literasi Dijital

Selain pemodelan sistem usulan dengan UML, pemodelan berikutnya adalah pemodelan terhadap data yang mengalir dan relasi antar data tersebut. Pemodelan terhadap data ini disajikan dalam bentuk conceptual data model (CDM) dengan ER-Diagram. Gambar 5 adalah ER-Diagram dari hasil pemodelan konseptual data.

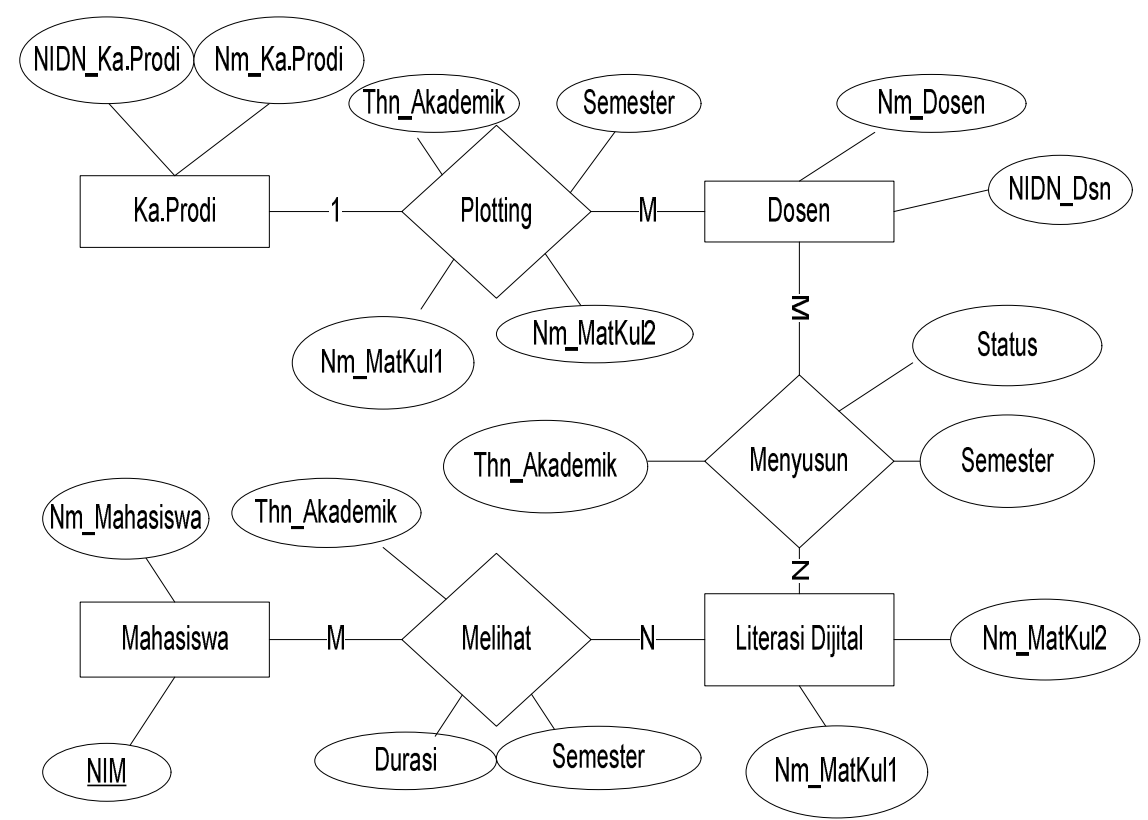

Gambar 4 ER-Diagram Sistem Literasi Dijital

Setelah tahap desain maka dilanjutkan dengan tahap pengumpulan material yang dibutuhkan dalam pembuatan produk. Adapun material yang dibutuhkan antara lain daftar mata 
kuliah, capaian pembelajaran mata kuliah, multimedia (suara, gambar, vidio, animasi, teks) pendukung, dan material lainnya yang dibutuhkan oleh pengembang sistem.

Tahap berikutnya adalah tahap assembly. Pada tahap ini dilakukan konversi hasil desain ke dalam bentuk bahasa pemrograman. Bahasa pemrograman yang diusulkan dalam penelitian ini adalah Java Script dengan aplikasi dibangun berbasis web. Hasil dari tahap ini merupakan produk akhir berupa aplikasi atau teknologi literasi dijital. Sesuai dengan hasil pada tahap desain maka aplikasi akan ditampilkan dalam bentuk antar muka grafis. Antar muka grafis dibagi menjadi tiga menu yaitu menu mahasiswa, menu dosen, dan menu ketua program studi. Masing-masing menu dapat diakses dengan memasukkan username dan password. Hal ini bertujuan agar tidak sembarangan pengguna dapat mengakses menu pada aplikasi. Setiap pengguna memiliki hak akses yang berbeda-beda sesuai dengan rancangan use case diagram sistem usulan. Gambar 5 adalah screen shoot dari media literasi dijital yang dihasilkan.

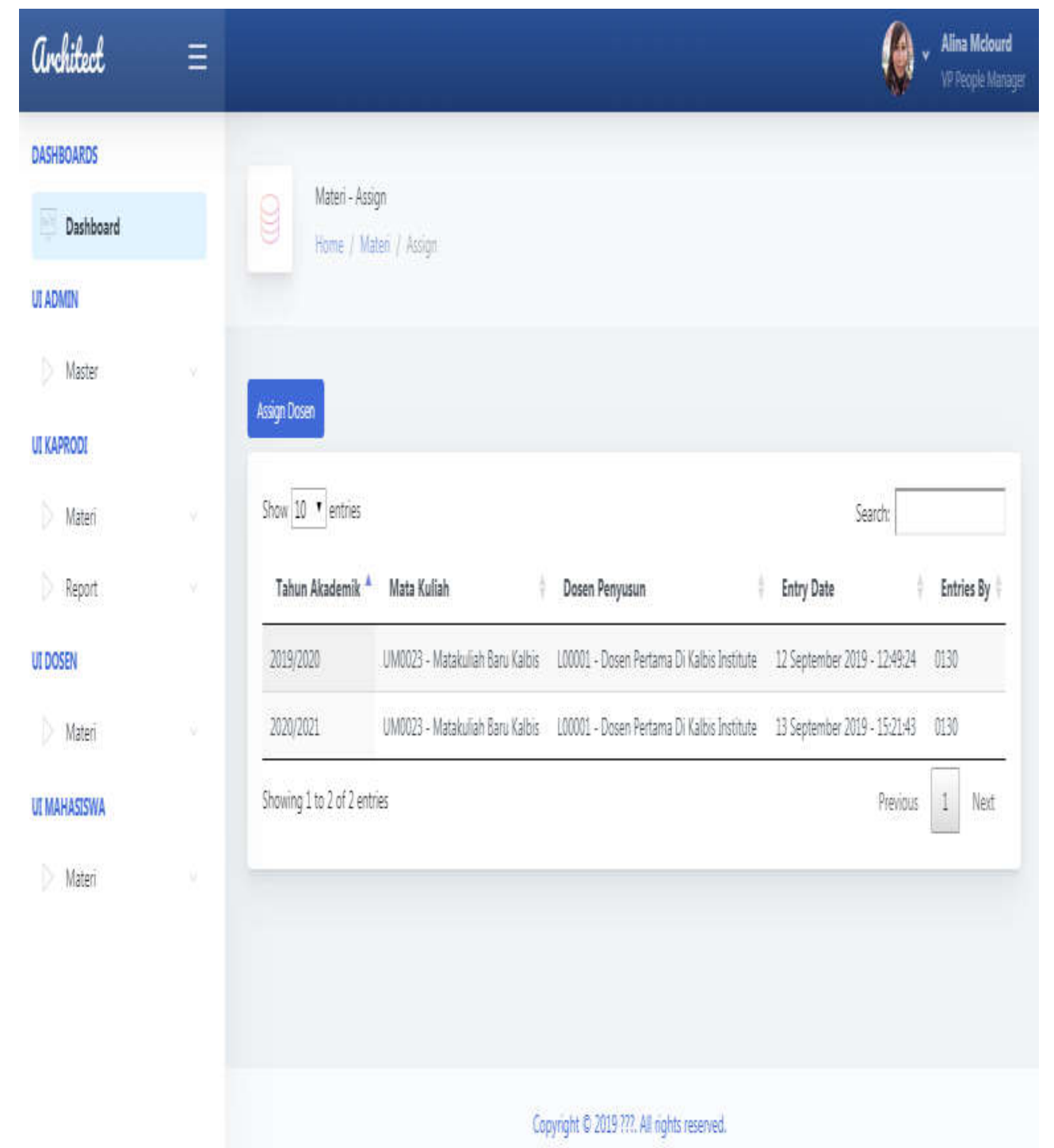

Gambar 5 Tampilan Antar Muka Grafis Sistem Literasi Dijital

\subsection{Uji Coba Produk Awal}

Setelah tahap assembly maka tahap berikutnya adalah tahap testing. Pada tahap ini kita kembali merujuk kapada tahap keempat dari metode $R \& D$ yaitu tahap uji coba awal. Mengingat 
bahwa produk yang dihasilkan adalah sebuah teknologi atau sistem maka ujicoba dilakukan dengan metode pengujian yang sesuai untuk teknologi atau sistem. Salah satu metode pengujian untuk teknologi adalah metode black box. Pada metode ini, pengujian dilakukan pada fungsional dari perangkat lunak nya. Pengujian ini melihat apakah ada ketidaksesuaian fungsi pada aplikasi berdasarkan spesifikasi dari perangkat lunak yang telah ditentukan di awal. Metode black box tidak memperhatikan struktur logika internal perangkat lunak. Tabel 2 merupakan cuplikan hasil ujicoba awal dari produk yang dihasilkan. Tabel tersebut disajikan berdasarkan pengguna dari sistem yaitu ketua program studi, dosen, dan mahasiswa.

Tabel 2 Hasil Uji Coba Produk Awal

\begin{tabular}{|c|c|c|c|c|}
\hline Pengguna & Butir Uji & Keterangan & Hasil Uji \\
\hline Dosen & Menu login & $\begin{array}{c}\text { Dosen harus memasukkan } \text { username dan password. Jika } \text { username dan } \\
\text { password benar maka akan masuk ke menu dosen. Tetapi } \text { username dan } \\
\text { password tidak sesuai dengan database maka akan mncul jendela notifikasi. }\end{array}$ & $\begin{array}{c}\text { Belum ada } \\
\text { notifikasi }\end{array}$ \\
\hline $\begin{array}{c}\text { Ketua } \\
\text { Studi }\end{array}$ & $\begin{array}{c}\text { Menu } \\
\text { Verifikasi }\end{array}$ & $\begin{array}{c}\text { Setelah melihat materi literasi yang diupload oleh dosen maka ketua program } \\
\text { studi dapat memutuskan apakah disetujui atau tidak dengan menekan tombol } \\
\text { approval. Jika sudah di approval maka materi literasi akan muncul di menu } \\
\text { mahasiswa. }\end{array}$ & $\begin{array}{c}\text { Sesuai dengan } \\
\text { kebutuhan } \\
\text { fungsional }\end{array}$ \\
\hline Mahasiswa & Menu & Mahasiswa dapat mengakses materi literasi yang telah dikirim oleh dosen dan \\
View & diverifikasi oleh ketua program studi & $\begin{array}{c}\text { Sesuai dengan } \\
\text { kebutuhan } \\
\text { fungsional }\end{array}$ \\
\hline
\end{tabular}

\subsection{Perbaikan Produk Awal}

Sesuai dengan hasil dari pengujian awal dengan metode black box maka selanjutnya dilakukan perbaikan-perbaikan terhadap produk yang dihasilkan. Adapun perbaikan terhadap produk yang dihasilkan meliputi fungsi (menu) entry dari dosen dan menu verifikasi dari ketua program studi. Pada menu verifikasi, sebaiknya selain tombol approval juga disediakan tombol reject.

\section{KESIMPULAN DAN SARAN}

Berdasarkan seluruh rangkaian kegiatan penelitian serta hasil yang diperoleh, berikut adalah kesimpulan yang dapat ditarik oleh tim peneliti:

1. Kombinasi dari metode R\&D dan MDLC dapat digunakan dalam penelitian ini dengan baik.

2. Dengan prinsip dari metode $R \& D$, maka kualitas dari materi literasi dijital dapat dijaga. Hal ini karena metode $R \& D$ sampai pada aktifitas memastikan efektifitas produk yang dihasilkan.

3. Dengan metode MDLC, materi literasi dijital yang dihasilkan dapat disajikan dengan melibatkan berbagai komponen multimedia seperti tekstual, gambar, suara, animasi, dan vidio sehingga materi literasi lebih menarik.

4. Materi literasi pada setiap mata kuliah dapat disesuaikan dengan kebutuhan pembelajaran di perguruan tinggi sehingga materi literasi yang disajikan lebih terstruktur dan sistematis.

\section{SARAN}

Dari seluruh hasil penelitian maka tim peneliti masih harus melakukan banyak inovasi seperti mengubah platform aplikasi dalam bentuk mobile sehingga lebih mudah diakses oleh pengguna. Selain itu, pada sistem yang dikembangkan dapat ditambahkan fitur chat online antara mahasiswa dengan dosen penyusun materi literasi dijital jika ada materi yang tidak difahami oleh mahasiswa. Selain itu, penelitian ini harus dilanjutkan ke tahap berikutnya sehingga evaluasi dampak dari penerapan produk literasi terhadap pengguna dapat dilakukan. Saat ini, penelitian baru selesai sampai kepada tahap perbaikan produk awal yaitu tahap kelima dari 10 tahap dalam metode R\&D. 
UCAPAN TERIMA KASIH

Terimakasih kepada Kalbis Institute yang telah mendukung pendanaan serta fasilitas pendukung untuk pelaksanaan penelitian ini sampai dengan selesai.

\section{DAFTAR PUSTAKA}

[1] B. Trilling and C. Fadel, 21st century skills : learning for life in our times, 1st ed. United States of America: Jossey-Bass, 2009.

[2] I. B. Bangkit Ardana, I Kadek; Surya Kartika, Luh Gede; Suradarma, "RANCANG BANGUN APLIKASI MEDIA PEMBELAJARAN PERKAWINAN AGAMA HINDU DALAM MANAWA DHARMASASTRA BERBASIS WINDOWS PHONE," JOSIKOM J. Online Sist. Komput., vol. 1, no. 1, p. 1, 2015.

[3] Z. Bahri and Sukamto, "APLIKASI EVALUASI PEMBELAJARAN BERBASIS MULTIMEDIA INTERAKTIF MENGGUNAKAN PHP DAN MYSQL," JIPI(Jurnal Ilm. Penelit. dan Pembelajaran Inform., vol. 2, no. 2, pp. 55-64, 2017.

[4] H. Sutopo, R. S. Samosir, and J. Gatc, "Mobile multimedia evaluation: Development of stop drugs tutorial," Int. J. Interact. Mob. Technol., 2019.

[5] H. T. T. Wahono and Y. Effrisanti, "Literasi Digital di Era Millenial," Pros. Semin. Nas. Has. Penelit. Pendidik. dan Pembelajaran STKIP PGRI Jombang, pp. 185-193, 2018.

[6] M. F. Akbar and F. D. Anggraeni, "Teknologi Dalam Pendidikan : Literasi Digital dan Self-Directed Learning pada Mahasiswa Skripsi," Indig. J. Ilm. Psikol., vol. 2, no. 1, pp. 28-38, 2017.

[7] N. Kurnia and S. I. Astuti, "Peta Gerakan Literasi Digital Di Indonesia: Studi Tentang Pelaku, Ragam Kegiatan, Kelompok Sasaran Dan Mitra," Inf. Kaji. Ilmu Komun., vol. 47, no. 2, p. 149, 2017.

[8] K. Ang, "Engaging the secondary school student in religious education classes: The four essentials," Relig. Educ., vol. 60, no. 1, pp. 15-22, 2012.

[9] S. Haryati, "Research and Developmet (R\&D) Sebagai Salah Satu Model Penelitian Dalam Bidang Pendidikan, " Majalah Ilmiah Dinamika, vol.37, no.1, pp.11-24, 2012.

[10] H. Anshary, W. Hidayat, and S. K. Sari, "Aplikasi Pembelajaran Berbasis Multimedia Tentang Kenampakan Alam dan Keadaan Sosia Benua-Benua Di Dunia Untuk Kelas Enam Sekolah Dasar," e-Proceeding Appl. Sci., vol. 2, no. 3, pp. 1113-1123, 2016.

[11] A. Dennis, B. H. Wixom, and D. Tegarden, System Analysis and Design: An objectoriented approach with UML, 5th ed. 2015.

[12] A.S.Rosa and M. Shalahuddin, Rekayasa Perangkat Lunak ( Terstruktur dan Berorientasi Objek). Bandung: Informatika, 2016.

[13] Saifulloh and N. Asnawi, "Data Manajemen Dan Teknologi Informasi," J. Ilm. DASI, vol. 16, no. 1, pp. 96-100, 2015. 